\title{
STRES DAN KOPING MAHASISWA KEPERAWATAN SELAMA PEMBELAJARAN DARING DI MASA PANDEMIK COVID-19
}

\author{
${ }^{1}$ Herna Angelica , ${ }^{2}$ Evelyn Hemme Tambunan \\ ${ }^{1,2}$ Program Studi S-1 Keperawatan, Universitas Advent Indonesia \\ Email: ${ }^{1}$ hernaangelica2000@gmail.com, 2 evelyntambunan@unai.edu
}

\begin{abstract}
ABSTRAK
Pembelajaran tradisional telah berganti menjadi pembelajaran daring sebagai implikasi dari kebijakan pencegahan penularan virus Covid-19 di Indonesia. Pembelajaran daring merupakan sistem pembelajaran baru di Indonesia yang menggunakan jaringan teknologi internet dan dapat memicu stres. Koping merupakan tanggapan terhadap perubahan sistem pembelajaran daring tersebut. Tujuan penelitian ini adalah untuk mengetahui gambaran tingkat stres dan koping pada mahasiswa selama pembelajaran daring di masa pandemik Covid-19. Jenis penelitian ini adalah deskriptif kuantitatif. Metode pengambilan sampling dalam penelitian ini adalah menggunakan convenience sampling. Sample penelitian adalah mahasiswa program studi pendidikan ners tahap akademik dan profesi di Fakultas Ilmu Keperawatan Universitas Advent Indonesia yaitu sebanyak 157 responden dengan waktu penelitian bulan September sampai November 2020. Instrument penelitian yang digunakan adalah kuesioner yang telah valid yaitu Depression Anxiety Stress Scale-42 (DDAS-42) dan strategi koping. Kuesioner dibagikan melalui google form dan data dianalisa menggunakan distribusi frekuensi untuk melihat gambaran tingkat stres dan koping yang digunakan dalam pembelajaran daring. Hasil penelitian menunjukkan sebagian besar yaitu 83 mahasiswa $(52,8 \%)$ berada pada tingkat stres normal, hampir sebagain besar yaitu 72 mahasiswa (45,9\%) menggunakan strategi koping berfokus pada emosi. Diharapkan tenaga pendidik dapat mengurangi tingkat stres mahasiswa dan mahasiswa dapat menggunakan strategi koping yang lebih efektif dalam pembelajaran daring. Menggali faktor-faktor stres dan hubungannya dengan strategi koping dalam pembelajaran daring adalah penting untuk penelitian lebih lanjut.
\end{abstract}

Kata kunci: Pembelajaran Daring, Mahasiswa Keperawatan, Stres Dan Koping.

\section{ABSTRACT}

Traditional learning has shifted into online learning as an implication of the Covid-19 virus transmission prevention policy in Indonesia. Online learning is a new learning system in Indonesia that uses internet technology networks that can trigger stress. Coping is a response to the changes in the learning system. This study aims to describe stress nd coping level of nursing students in online learning during Covid-19 pandemic. The type of this research is a quantitative descriptive. The sampling method in this study uses convenience sampling. The sample of this study is nursing students in both academic and profession program at Faculty of Nursing Science in Universitas Advent Indonesia, as many as 157 respondents within the month of September to November of research period. Both valid instruments used in this study are Depression Anxiety Stress Scale-42 (DDAS-42) and coping strategy questionnaires. Questionnaires were distributed via google form and data were analyzed using frequency distribution to describe the level of stress and coping utilization in online learning. The results showed that majority of the respondents totaled 83 students (52.8\%) were at normal stress levels, and emotion-focused coping were manifested by 72 students (45.9\%). It is recommended that faculty need to reduce students' stress level whilst students would utilize the best coping strategy encountered in online learning. Though exploring stress factors related to coping strategy in online learning is essential for further study.

Keywords: Online Learning, Nursing Students, Stress And Coping.

\section{PENDAHULUAN}

Pandemik Covid-19 telah membawa dampak dalam sistem pembelajaran di seluruh dunia. Pembelajaran tradisional telah berganti menjadi pembelajaran daring oleh adanya kebijakan pencegahan penularan virus Covid-19 (Siahaan, 2020). Corona Virus saat ini menyebar ke 215 negara untuk itu bidang pendidikan terlebih lagi perguruan tinggi memiliki tantangan khusus dalam pembelajaran (Sadikin \& Hamidah, 2020).

Upaya pencegahan yang dilakukan pemerintah dalam mengurangi penyebaran Covid-19 adalah pembatasan sosial berskala 
besar, dengan cara menjaga jarak kontak fisik, menggunakan masker, dan mencuci tangan setelah beraktivitas. Selain itu pula kebijakan tetap tinggal di rumah dimana melakukan seluruh kegiatan dari rumah, termasuk bekerja dan belajar (Permenkes RI, 2020). Dengan demikian pembelajaran secara konvensional berganti menjadi pembelajaran secara daring. Hal ini dikukuhkan dengan adanya kebijakan yang dikeluarkan oleh Kementrian Pendidikan dan Kebudayaan Pemerintah Indonesia yaitu peraturan untuk melakukan pembelajaran secara daring menggantikan pembelajaran secara tatap muka (Kemendikbud, 2020; Yuliati dan Saputra, 2020).

Pembelajaran secara daring merupakan metode pembelajaran yang menggunakan jaringan teknologi internet. Metode pembelajaran daring bisa dilakukan dimana saja asalkan memiliki jaringan internet. Penggunaan berbagai alat bantu seperti laptop, telefon genggam ataupun alat lain menjadi sarana dalam pembelajaran daring. Lebih lanjut, lingkungan pembelajaran daring dapat berupa synchronous dan asynchronous. Pada lingkungan pembelajaran daring synchronous, terjadi interaksi langsung antara tenaga pendidik dan mahasiswa. Pembelajaran daring dapat dilakukan dengan webinar secara live ataupun kegiatan tatap muka menggunakan aplikasi zoom atau google classroom, dsb. Sedangkan pada asynchronous tidak terjadi interaksi secara langsung, dimana penggunaan sarana belajar dapat berupa email, blog dan rekaman materi melalui video (Hidayah et al., 2020; Basilaia, et al, 2020; Singh \& Thruman, 2019).

Sistem pembelajaran daring merupakan sistem pembelajaran yang belum umum dilaksanakan di Indonesia. Kementrian Pendidikan dan Kebudayaan Pemerintah Indonesia telah memperkenalkan Universitas Terbuka dimana sistem pembelajaran jarak jauh dilaksanakan (Sistem Pendidikan Nasional, 2003). Sebelum era pandemik Covid-19, terdapat 9 perguruan tinggi yang telah melaksanakan program pendidikan jarak jauh dan hanya satu dilaksanakan oleh pendidikan keperawatan (Irwansyah, 2018, Taufik, 2019). Namun pembelajaran daring diwajibkan pada masa pandemi Covid-19 ini sehingga semua institusi pendidikan keperawatan melaksanakan pembelajaran daring walaupun mengalami berbagai kendala (Argaheni, 2020). Beberapa hal yang menjadi masalah bagi mahasiswa dalam implementasi pembelajaran daring seperti, pemahaman penggunaan teknologi yang masih minim, jaringan yang tidak stabil, biaya yang dikeluarkan untuk internet, dan masalah psikologis yaitu stress yang dihadapi mahasiswa (Rasyida, 2020).

Beberapa penelitian menunjukkan adanya dampak stres pada mahasiswa akibat penerapan pembelajaran secara daring. Tingkat stres akademik mahasiswa berada dalam berbagai rentang, dari tinggi, sedang dan rendah (Harahap, 2020). Stres dalam pembelajaran daring dapat berupa tugas yang banyak, kebosanan yang mulai timbul karena sistem daring, adanya keterbatasan dalam bertemu dengan teman-teman yang dicintai, tidak aktif berpartisipasi karena koneksi internet yang buruk, dan tidak ada praktik laboratorium (Livana, Mubin, Basthomi, 2020). Berbagai stres dalam proses belajar dapat mempengaruhi sikap mental dan juga hasil belajar mahasiswa (Muiz, et al, 2020; Barseli, Ahmad, Ifdil, 2020).

Stres adalah suatu reaksi yang normal terhadap berbagai tekanan, namun dapat merusak kesehatan apabila mengganggu aktifitas sehari-hari (APA, 2019). Stres yang dialami mahasiswa dalam pembelajaran daring akan mendapat tanggapan yang berbeda-beda pada setiap individu tersebut. Tanggapan dapat berupa koping yaitu upaya untuk meminimalkan dampak stres dalam pembelajaran daring (Fitriasari, Septianingrum, Budury, dan Khamida, 2020). Menurut APA (2019), terdapat dua strategi koping yang biasanya menjadi strategi bagi setiap individu dalam menghadapi stres yaitu emotion-focused coping dan problem-focused coping. Pada emotion-focused coping, individu cenderung menggunakan strategi koping yang berfokus pada pengaturan dan reaksi emosi terhadap penyebab stres. Individu pada kondisi ini cenderung merubah penyebab stres dan mengontrol perasaan yang timbul dengan menggunakan berbagai perilaku kognitif seperti meditasi, tehnik relaksasi atau berbagai strategi yang bersifat positif lainnya. Namun tidak menutup kemungkinan individu dapat menggunakan strategi menghindar, menyalahkan diri sendiri, menarik diri, atau berbagai perilaku 
negatif lainnya. Sedangkan problem-focused coping adalah strategi koping dimana individu secara langsung menghadapi serta menyingkirkan penyebab stres yang ada. Individu cenderung menciptakan solusi-solusi datau berbagai bentuk tindakan untuk mengatasi stres (Lazarus dan Folkman, 1984 dalam APA, 2019).

Program studi pendidikan ners di Universitas Advent Indonesia (UNAI) terdiri dari tahap akademik dan profesi. Pembelajaran daring telah dilaksanakan sejak semester genap tahun akademik 2019/2020 hingga saat penelitian ini dilakukan yaitu semester genap tahun akademik 2020/2021. Sistem pembelajaran tatap muka baik di dalam kelas, laboratorium dan klinis telah digantikan dengan sistem pembelajaran secara daring. Perubahan sistem pembelajaran daring yang telah dilaksanakan dapat memberikan informasi tentang gambaran tingkat stres dan koping yang digunakan mahasiswa keperawatan UNAI dalam pembelajaran daring di masa pandemik Covid-19.

\section{METODE}

Disain penelitian yang digunakan dalam penelitian ini adalah deskriptif kuantitatif untuk mendeskripsikan stres dan koping mahasiswa keperawatan selama pembelajaran daring di masa pandemik Covid-19. Pembelajaran daring telah diterapkan sejak pertengahan semester genap tahun akdemik 2019/2020 hingga saat penelitian dilakukan yaitu semester genap tahun akademik 2020/2021. Populasi dari penelitian yaitu seluruh mahasiswa program studi pendidikan ners pada tahap akademik dan profesi di Fakultas Ilmu Keperawatan UNAI. Dengan menggunakan metode convenience sampling sebanyak 157 orang responden bersedia dengan sukarela mengisi kuesioner dengan kriteria inklusi yaitu mahasiswa keperawatan di program studi ners tahap akademik dan tahap profesi yang mengikuti pembelajaran daring sejak bulan Maret sampai Desember 2020. Sedangkan kriteria ekslusi adalah mahasiswa yang tidak mengisi kuesioner secara lengkap. Periode pengumpulan data dimulai dari bulan September sampai November 2020 dimana kuesioner disebarkan melalui google form. Jumlah responden ditentukan menggunakan formula Slovin (Setiawan, 2007).

Kuesioner Depression Anxiety Stress Scale-42 (DDAS-42) yang telah valid dengan nilai validitas $\alpha=.9483$ dan nilai reliabilitas $\mathrm{r} \geq=.3$ yang digunakan dalam peneltiian ini diperoleh dari (Psychology Foundation of Australia, 2014) dan telah diterjemahkan oleh (Damanik, 2014) ke dalam Bahasa Indonesia adalah untuk mengukur stres selama pembelajaran daring. Indikator penilaian tingkat stres adalah sebagai berikut: normal (0-14), ringan (15-18), sedang (19-25), parah (26-33) dan sangat parah (>34). Sedangkan gambaran koping yang digunakan oleh mahasiswa keperawatan diukur menggunakan kuesioner strategi koping yang dikembangkan dari teori strategi stres koping. Indikator koping digambarkan dengan koping berfokus pada masalah, emosi dan digunakan bersama-sama secara seimbang. Uji validitas dan realibilitas instrumen koping adalah sebesar 0.81 (Kresna, 2016).

Pengumpulan data dimulai setelah mendapatkan persetujuan etik melalui SK ketua komisi etik penelitian kesehatan Fakultas Ilmu Keperawatan UNAI dengan nomor 158/EKS-SU-VIII/20. Informed Consent diberikan kepada mahasiswa untuk meminta persetujuan mengisi kuesioner tanpa adanya paksaan oleh peneliti dan setiap responden dapat mengundurkan diri tanpa ada sanksi sewaktu-waktu. Setiap rahasia responden adalah privasi dan hanya dipergunakkan untuk kepentingan penelitian. Analisa data dalam penelitian ini terdiri dari satu tahap yaitu mengumpulkan kuesioner yang terisi dengan lengkap, kemudian dianalisa menggunakan frekuensi distribusi. Analisa kuantitatif berguna untuk menggambarkan stres dan strategi koping responden pada tiap tingkat pendidikan yaitu pada tahap akademik dan profesi.

\section{HASIL DAN PEMBAHASAN 3.1 Hasil}

Hasil penelitian akan dijelaskan dengan tabel sub bab ini, mencakup karakteristik responden, distribusi frekuensi tingkat stres dan strategi koping. 
Tabel 1. Karakteristik Responden

Berdasarkan Jenis Kelamin, Usia Dan Tingkat Pendidikan

\begin{tabular}{|c|c|c|c|}
\hline No & $\begin{array}{c}\text { Karakteristik } \\
\text { Responden } \\
\end{array}$ & $\begin{array}{c}\text { Jumlah } \\
\text { (n) }\end{array}$ & $\begin{array}{c}\text { Persentase } \\
(\%)\end{array}$ \\
\hline \multirow[t]{4}{*}{1} & Jenis Kelamin & & \\
\hline & Laki-laki & 51 & 32.5 \\
\hline & Perempuan & 106 & 67.5 \\
\hline & Total & 157 & 100.0 \\
\hline \multirow[t]{6}{*}{2} & Usia & & \\
\hline & $18-22$ & 116 & 73,9 \\
\hline & $23-27$ & 34 & 21,7 \\
\hline & $28-32$ & 3 & 1,8 \\
\hline & $>33$ & 4 & 2,4 \\
\hline & Total & 157 & 100.0 \\
\hline \multirow[t]{6}{*}{3} & Tingkat Pendid & Kan & \\
\hline & 2 & 28 & 17.8 \\
\hline & 3 & 33 & 21.0 \\
\hline & 4 & 45 & 28.7 \\
\hline & Profesi & 51 & 32.5 \\
\hline & Total & 157 & 100.0 \\
\hline
\end{tabular}

Berdasarkan pemaparan tabel 1 diatas didapatkan bahwa dari jumlah responden sebanyak 157 mahasiswa yaitu sebagian besar responden berjenis kelamin perempuan sebanyak 106 orang (67,5\%). Sedangkan berdasarkan usia, sebagian besar dari responden yaitu 116 orang $(73,9 \%)$ berada pada rentang usia 18-22 tahun. Berdasarkan tingkat pendidikan, mahasiswa profesi sebanyak 51 orang $(32,5 \%)$.

Tabel 2. Distribusi Frekuensi Tingkat Stres

No Hasil Tingkat Frekuensi Persentase

\begin{tabular}{clcc} 
& \multicolumn{1}{c}{ Stres } & $(\mathbf{n})$ & $\mathbf{( \% )}$ \\
\hline 1 & Normal & 83 & 52,8 \\
\hline 2 & Ringan & 28 & 17,8 \\
\hline 3 & Sedang & 21 & 13,4 \\
\hline 4 & Parah & 18 & 11,5 \\
\hline 5 & Sangat Parah & 7 & 4,5 \\
\hline & Total & 157 & 100 \\
\hline
\end{tabular}

Berdasarkan hasil tabel 2 diatas dapat dijelaskan bahwa distribusi tingkat stres berada pada normal sebanyak 83 orang $(52,8 \%)$ atau sebagian besar dari responden berada pada tingkat stres normal.

Tabel 3. Distribusi Frekuensi Strategi Koping

\begin{tabular}{cccc}
\hline No & $\begin{array}{c}\text { Strategi } \\
\text { Koping }\end{array}$ & $\begin{array}{c}\text { Frekuensi } \\
(\mathbf{n})\end{array}$ & $\begin{array}{c}\text { Presentase } \\
(\boldsymbol{\%})\end{array}$ \\
\hline 1 & Fokus Emosi & 72 & 45.9 \\
\hline 2 & Fokus Masalah & 46 & 29.3 \\
\hline 3 & Seimbang & 39 & 24.8 \\
\hline & Total & 157 & 100 \\
\hline
\end{tabular}

Berdasarkan hasil tabel 3 di atas dapat dijelaskan bahwa hampir sebagain besar mahasiswa menggunakan strategi koping berfokus kepada emosi yaitu sebanyak 72 orang $(45,9 \%)$.

\subsection{Pembahasan}

Penelitian yang dilakukan oleh (Andiarna dan Kusumawati, 2020), menunjukkan bahwa pembelajaran daring mempengaruhi stress akademik selama pandemik Covid-19. Beberapa dampak perkuliahan daring saat pandemik Covid-19 menurut (Argaheni, 2020), mencakup: 1).Pembelajaran daring masih membingungkan mahasiswa, 2).Mahasiswa menjadi pasif, kurang kreatif dan produktif, 3).Penumpukan informasi/konsep pada mahasiswa kurang bermanfaat, 4).Mahasiswa mengalami stres, dan 5).Peningkatan kemampuan literasi bahasa mahasiswa. Namun kesimpulan yang didapat dari penelitian (Iskandar, dkk, 2020) adalah berbagai kondisi sistem pembelajaran daring pada mahasiswa keperawatan telah dapat diterima oleh civitas akademika keperawatan di universitas Abulyatama.

Strategi koping yang dilakukan mahasiswa dalam menghadapi sistem pembelajaran daring bervariasi. Strategi koping dapat berupa strategi berfokus kepada masalah melalui perencanaan pemecahan masalah dan mencari dukungan sosial. Namun strategi koping yang berpusat pada emosi melalui penilaian kembali secara positif dan kontrol diri (Damayanti dan Masitoh, 2020). Penelitian ini mendukung hasil penelitian yang didapati dalam penelitian ini, dimana terdapat sebagian besar mahasiswamenggunakan strategi koping berfokus pada emosi. Lebih lanjut, strategi koping berfokus pada masalah atau secara bersamaan menggunakan kedua strategi tersebut juga didapati dalam penelitian ini. Hasil penelitian ini sejalan dengan hasil penelitian yang didapat oleh (Fitriasari, Septianingrum, Budury, dan Khamida, 2020) dimana strategi koping dominan berfokus pada emosi. Pada strategi ini mahasiswa mengatasi stres dengan mengatur emosi yang dirasakannya. Sedangkan strategi koping berfokus pada masalah yang dilakukan mahasiwa dalama mengatasi stres dalam pembelajaran daring adalah dengan cara 
mengubah masalah yang menyebabkan potensi timbul adanya tekanan. Sebagaimana (Lazarus, Susan Folkman, 1984 dalam Raudha dan Thahlil, 2016) menjelaskan bahwa strategi koping berfokus pada masalah cenderung berusaha memecahkan masalah atau mencari informasi untuk menyelesaikan masalah yang dihadapi.

\section{KESIMPULAN}

Hasil penelitian ini menunjukkan bahwa sebagian besar dari mahasiswa keperawatan di Universitas Advent Indonesia mengalami stres dalam tingkat yang normal. Lebih lanjut, koping mahasiswa dalam mengatasi stres pembelajaran daring adalah hampir sebagian besar menggunakan koping berfokus pada emosi.

Dari hasil penelitian yang dipaparkan di atas peneliti menyarankan agar tenaga pendidik mengurangi tingkat stres dalam pembelajaran daring pada mahasiswa program studi pendidikan ners tahap akademik dan profesi di Universitas Advent Indonesia. Saran bagi mahasiswa keperawatan adalah untuk dapat menggunakan strategi koping yang efektif dalam mengatasi stres dalam pembelajaran daring.

Peneliti juga berharap penelitian ini dapat dikembangkan dalam penelitian selanjutnya untuk menggali lebih dalam faktor-faktor yang menyebabkan stres dalam pembelajaran daring. Hal ini dapat memberikan gambaran pengelolaan sumber stres dan hubungannnya dengan penggunaan koping dalam pembelajaran daring.

\section{REFERENCES}

American Psychological Association. (2019). Stress relief is within reach. Diakses di https://www.apa.org/topics/stress

Andiarna, F., Kusumawati, E. (2020). Pengaruh Pembelajaran Daring terhadap Stres Akademik Mahasiswa Selama Pandemi Covid-19. Jurnal Psikologi, 16 (2), 139-149.

Argaheni, N. B. (2020). Sistematik Review: Dampak Perkuliahan Daring Saat Pandemi Covid-19 Terhadap Mahasiswa Indonesia. PLACENTUM: Jurnal Ilmiah Kesehatan Dan Aplikasinya, 8(2), 99. Diakses di https://doi.org/10.20961/placentum.v8i2. 43008.
Barseli, M., Ahmad, R.M., Ifdil, I. (2020). Hubungan stres akademik siswa dengan hasil belajar. Jurnak EDUCATIO, 4(1), 40-47. Diakses di http://jurnal.iicet.org/.

Basilaia, G., Dgebuadze, M., Kantaria, M., Chohonelidze, G. (2020). Replacing the classic learning form at universitites as an immediate response to the Covid-19 virus infection in Gerogia. International Journal for Research in Applied Science \& Engineering Technology, 8 (III).

Damayamti, D.T., Masitoh, A. (2020). Strategi koping siswa dalam menghadapi stres akademik di era pandemi Covid-19. Adacemia Journal of Multidisciplinary Studies, 4 (2), 185-198.

Fitriasari, A., Septianingrum, Y., Budury, S., Khamida, K. (2020). Stres pembelajaran online berhubungan dengan strategi koping mahasiswa selama pandemi covid-19. Jurnal Keperawatan Stikes Kendal, 12 (4), 985-992.

Hamzah, B,. Hamzah, R. (2020). FaktorFaktor Yang Berhubungan Dengan Tingkat Stres Akademik Pada Mahasiswa Stikes Graha Medika. Indonesian Journal for Health Sciences, 4(2), 59. https://doi.org/10.24269/ijhs.v4i2.2641 Diakses http://journal.umpo.ac.id/index.php/IJH S/article/view/2641.

Harahap, A,C., Harahap, D.P., Harahap, S.R. (2020). Analisis tingkat stres akademik pada mahasiswa selama pembelajaran jarak jauh di masa Covid-19. Biblioconus: Jurnal Kajian Konseling dan Pendidikan, 3(1), 10-14. Diakses di https://jurnal.umsu.ac.id/index.php/bibli o.

Hidayah, A. A. F., Al Adawiyah, R., \& Mahanani, P. A. R. (2020). Efektivitas Pembelajaran Daring di Masa Pandemi Covid 19. JURNAL SOSIAL: Jurnal Penelitian Ilmu-Ilmu Sosial, 21(3), 5356. Diakses di http://sosial.unmermadiun.ac.id/index.p hp/sosial/article/view/61.

Irwansyah. (2018). Penyelenggaraan Sistem Pendidikan Tinggi Jarak Jauh di Perguruan Tinggi Swasta. Jurnal Analisis Sistem Pendidikan Tinggi. Forum Dosen Indonesia, 2(1),39-50. 
Iskandar, Masthura, S., \& Oktabiyana, C. (2020). Penerapan Sistem Pembelajaran Daring Pada Mahasiswa Keperawatan Universitas Abulyatama. Jurnal Dedikasi Pendidikan,4(2), 323-332. Diakses di http://jurnal.abulyatama.ac.id/index.php /dedikasi/article/download/1058/pdf.

Kemendikbud. (2020). Surat Edaran Nomor 2 Tahun 2020 Tentang Pencegahan dan Penanganan Corona Virus Disease (COVID-19) di Kementrian Pendidikan dan Kebudayaan. Diakses di https://drive.google.com/file/d/14q3KYu KKddkQmSKrJXoA5FwCIuJV2IFR/view

Kresna, P. (2016). Dalam Proses Penyelesaian Skripsi Pada Mahasiswa Fakultas Kedokteran Universitas Udayana Tahun 2016. Diakses di https://ojs.unud.ac.id/index.php/eum/arti cle/view/66589.

Livana,P.H., Mubin, M.F.,\& Basthomi, Y. (2020). Penyebab Stres Mahasiswa Selama Pandemi Covid-19. Jurnal Ilmu Keperawatan Jiwa, 3(2), 203-208. Diakses di https://journal.ppnijateng.org/index.php/ jikj/article/download/590/329.

Muiz, M.H., Sumarni, N., Mansyur, A.S., Zaqiah, Q,Y. (2020). Pengaruh teknologi pembelajaran kuliah online di era Covid19 dan dampaknya terhadap mental mahasiswa. Jurnak Edukasi dan Teknologi Pembelajaran, 1(2). Diakses dari https://doi.org/10.37859/eduteach.v1i2.1 987.

Peratauran Menteri Kesehatan Republik Indonesia No. 9 Tahun 2020. Pedoman Pembatasan Sosial Berskala Besar Dalam Rangka Percepatan Penanganan Covid-19.

Ramadhanti, I. F., Hidayati, N. O., \& Rafiyah, I. (2019). Gambaran Stressor dan Strategi Koping pada Mahasiswa Tahun Pertama Fakultas Keperawatan Universitas Padjadjaran. Jurnal Pendidikan Keperawatan Indonesia, 5(2). Diakses di https://doi.org/10.17509/jpki.v5i2.16635

Rasyida, H. (2020). Efektivitas Kuliah Daring Di Tengah Pandemik. Jurnal
Edukasi, $\quad 1$ (November), $\quad 1-8$. https://edarxiv.org/n9ub2/.

Raudha, R., Tahlil, T. (2016). Stres dan strategi koping pada mahasiswa keperawatan. JIM FKep 1(1), 1-7.

Sadikin, A., \& Hamidah, A. (2020). Pembelajaran Daring di Tengah Wabah Covid-19. Biodik, 6(2), 109-119. Diakses https://doi.org/10.22437/bio.v6i2.9759.

Setiawan, N. (2007). Penentuan Ukuran Sampel Memakai Rumus Slovin dan Tabel Krejcie-Morgan: Telaah Konsep dan Aplikasinya. Diskusi Ilmiah Jurusan Sosial Ekonomi Fakultas Peternakan UNPAD, November, 1-10. Diakses di http://pustaka.unpad.ac.id/wpcontent/uploads/2009/03/penentuan uku ran_sampel_memakai_rumus_slovin.pdf

Siahaan, Matdio. 2020. "Dampak Pandemi Covid-19 Terhadap Dunia Pendidikan." Jurnal Kajian Ilmiah 1(1):73-80. doi: 10.31599/jki.v1i1.265.

Singh, V., \& Thruman, A. (2019). How many ways can we define online learning? A systematic literature review of definitions of online learning (19882018). American Journal of Distance Education, 33(4), 289-306.

Suryati. (2016). Sistem Manajemen Pembelajaran Online, Melalui. Jurnal Raden Fatah, PEMBELAJARAN ONLINE, 60-76. Diakses di http://jurnal.radenfatah.ac.id/index.php/ ghaidan/article/view/2034/1543.

Taufik, A. (2019). Perpspektif Tentang Perkembangan Sistem Pembelajaran jarak Jauh di Kabupaten Kutai Kartanegara Kalimantan Timur. Jurnal Pendidikan: Riset dan Konseptual, 3(2), 88-98.

Yudi Firmansyah, \& Fani Kardina. (2020). Pengaruh New Normal Ditengah Pandemi Covid-19 Terhadap Pengelolahan Sekolah Dan Peserta Didik. Buana Ilmu, 4(2), 99-112. Diakses https://doi.org/10.36805/bi.v4i2.1107.

Yuliati, Y., \& Saputra, D. S. (2020). Membangun Kemandirian Belajar Mahasiswa Melalui Blended Learning Di Masa Pandemi Covid-19. Jurnal Elementaria Edukasia, 3(1), 142-149. 
Diakses di

http://jurnal.unma.ac.id/index.php/jee/ar ticle/view/2218.

Yuwono, S. D. (2020). Profil Kondisi Stres

Di Masa Pandemi Covid-19 Sebagai

Dasar Intervensi Dalam Praktek
Mikrokonseling. Ristekdik: Jurnal

Bimbingan Dan Konseling, 5(1), 132-

138.

Diakses

di

http://garuda.ristekbrin.go.id/documents Idetail/1729639.

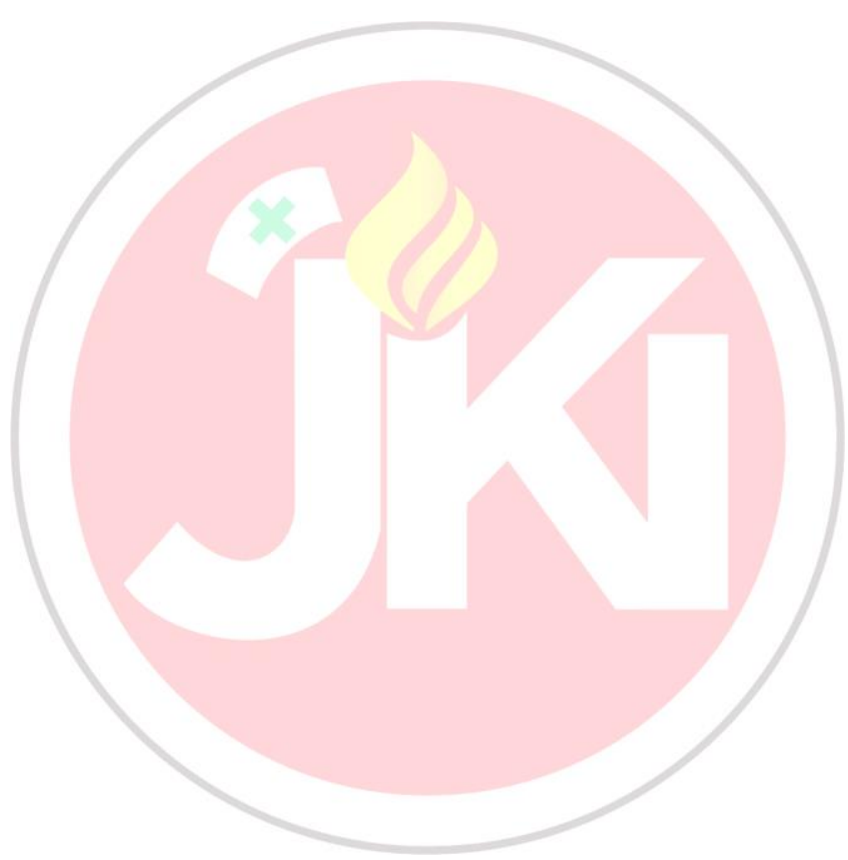

